\title{
Study on the Dynamic Financial Management Mode under E-commerce
}

\section{Era}

\author{
Cui Jie ${ }^{1}$ \\ ${ }^{1}$ Shaanxi Xueqian Normal University, Xi'an, Shaanxi, 710100 \\ 346591653@163.com
}

KEYWORDS: E-commerce; Dynamic Financial Management; Discussion

\begin{abstract}
China has entered the 21st century, Chinese scientific, economic, political culture has made great development. Which lead to the development of science and technology rapid increase of China's information technology industry. Currently, set off a worldwide e-commerce boom, and quickly gained popularity around the world, and its importance people wonder. At this stage, the development of enterprises increasingly depends on the level of development of science and technology, and the advent of e-commerce enterprises to inject new vitality, its business management has had a huge impact, and financial management as the foundation and core of enterprise management, we must closely follow the pace of development of the times, understand the current trends and to make a change, otherwise it will cause companies not estimate what the loss. Dynamic financial management system as the core, we must factor in the era of e-commerce to conduct a comprehensive consideration, in order to promote the rational development of corporate financial management, and further to seize business development opportunities.
\end{abstract}

\section{Introduction}

In the new century, the environment, information technology is the leader in modern science and technology and economic development. People can feel the life and production time to bring the power of information technology services. Enterprises in the information technology era not only have development opportunities, but also face enormous challenges. A plan view of the current form of business development, although the surface reflects the calm patterns of development, actually happening "Copernican revolution," one of the most highlighted places in the competitive environment and the management of the two modules. IT under the impact of the Internet wave of the global economy, causes social world undergoing fundamental changes. Enterprise Financial Management closely followed the development of forms of social times, and through constant innovation and development of enterprises to create competitive advantages but also for social and economic development make a significant contribution.

\section{The Traditional Financial Management Model}

A. Centralized Type

Group decision-making power is to master financial management, its Group subsidiaries under centralized control, through with audits, cost analysis methods used, aggregating management. In 
this management model, the company will total the financial management by the parent company, a subsidiary of the parent company to rely on the supply of basic operation and maintenance of the company to carry out activities. Under this type of centralized financial management and control model, it has great disadvantages, one is a subsidiary of independent innovation capability constraints, enthusiasm and flexibility of the development, on the other hand is the parent company of the decision-making once the errors, it will cause the entire company great harm. The main reason the company is highly concentrated in the subsidiary's financial management authority.

\section{B. Decentralizing}

A reasonable division of the main rights group financial management, decision-making authority in accordance with the principles of subsidiary and other importance. Group of companies focuses on the comprehensive development of the overall company strategy and important decisions development direction. Subsidiaries are under decentralized fiscal management to fully mobilize the enthusiasm and to seize the business opportunities through independent decisions. Group decision-making in this mode greatly reduced pressure. In this group management decision-making power and interference by certain weaken, causing major problems occur when a subsidiary failed to discover. In addition, under the command of disagreement decision, the parent company and subsidiaries are unable to reach unity of business metrics and financial indicators, leading to the loss of group interests.

\section{Type Fusion of Eentralization and Decentralization}

Type centralization and decentralization financial management model is a combination of both integrated mode function. Centralization to decentralization need to be consolidated, giving administrative rights must master a certain extent, between the company and the members of the company, this management model is a bottom-up strategy. Since the company to members of the company's daily operations very active, so the subject is too centralized financial, but can be balanced through timely separation of powers, such as the members of the company's business decision-making, financial management and company personnel appointment decision rights.

\section{The Traditional Financial Management in Managing the Impact of E-commerce Era}

\section{A. Changing the Financial Management of the Environment}

With the rapid development of economic globalization, the traditional economy gradually transformed for the integration, resource sharing, diversified economy. In this economic model, the traditional economy more in the office, two modules to give highlights consumption, such as a personal home network shopping and office and so on. Business model is to seize the characteristics of their development, to change the traditional management, enterprise management, for example to establish a virtual enterprise, the use of network finance. In the Internet, development of information technology environment, companies must in the new competitive pressure to find a new breakthrough in the current operation of the virtual network for sales and perfected a complete chain, enterprise financial management applied to network management environment next, not only the internal financial management function has been added, but also extends to outside the enterprise.

Financial management in support of network technology has been advanced, broad approach, under the company's existing financial management. Integration of enterprise infrastructure and information technology resources to achieve the purpose of resource integration, financial integration will transform the network for network finance, in this environment friendly, Kingdee 
tripartite network effectively use financial software, financial management and to further facilitate real-time dynamic property development process management.

The current large-scale use of electronic social accounts and online banking and other financial institutions to provide security for corporate financial management, reliability of financial security in the global trade is no longer subject to the space available for free trade and capital flows, further buyers and sellers have been reduced transaction costs. Internet Economy will directly affect the working methods and forms of corporate financial management.

\section{B. Change the Contents of the Financial Management}

Enterprise financial management will occur under the influence of e-commerce important change is reflected in the specific content of corporate financial allocation, financial analysis, corporate financing and investment. Enterprise management is the most basic financial management, does not appear until the network economy, the financial capital plays a dominant role, with flourish and after its comprehensive human resources, patents and other intangible assets, and gradually move towards a decisive position, so as to develop a stage of intellectual capital. In this stage, the corporate capital structure by the impact of knowledge capital and undergoing changes in order to conform to this change, corporate financial management center will be gradually transferred to the enterprise technology research, the personnel structure. With the current social forms of development gradually become severe, business environment factors also will be changed, such as corporate finance, financing, etc. gradually expand the scope, further increases the risk of the enterprise, thus enriching the content management of financial management.

\section{The Inappropriate Analysis of Financial Management in the Traditional E-commerce}

Social development in the 21st century, since the age of electronic commerce itself has very good properties can not accept the traditional financial management model, through long-term practice of analysis the following reasons:

First, the traditional financial management to enterprise risk can not play an effective preventive role. In the past, the traditional corporate financial management computerization, although to get the promotion, but it is only within the enterprise level domains, use and share range is to provide only the enterprise, information on the intrusion of the outside world and can not play an effective deterrents and the pitfalls of the Internet has not made sufficient consideration. Financial analysis as an important trade secrets of business development, internal security measures could lead to failure to implement its secret leaks. Once leaked trade secrets emerge, companies will suffer huge losses.

Second, the enterprise fund-raising, investment and management business and other economic activities, traditional financial management information can not be collected and processed, for the relevant national policy can not make a positive response and adjustment, which is long-term business development and competitiveness will adverse effect. In addition, traditional financial management in business planning, due to its limitations can not effectively avoid risks, resulting in a competitive advantage can not be promoted.

Third, since the security of enterprise information in the traditional financial management can not be effectively protected, usually handwritten signature corporate financial management, signed by way of ensuring security and the real content of the document. But in the present, with the rapid development of network information technology, password authentication, verify that the differentiated approach will result in a waste of manpower financial, but also result in the possibility of information leakage. In the context of a new era, all kinds of electronic statements, bills and other 
non-paper documents gradually get used, if the lack of cases of misappropriation will cause I signed the law on the protection of such events is not comprehensive enough.

\section{The Financial Management Mode of Dynamic E-Commerce Era}

\section{A. Network of Financial Services}

Internet e-commerce financial processes spawned a new financial management model, which has rich theoretical basis and accounting practices in full compliance with the contemporary economic environment. But in such a complex environment network environment, the network is not enough merely to implement the financial aspects. In addition to the actual environment for the development and management of corporate and business level and so on, but also integration in the enterprise at all levels and in all aspects of the financial network, in order to make reasonable financial network and comprehensive use, thus contributing to a balanced development of the various levels of corporate functions, further integration of the lateral and vertical business process management process.

\section{B. Dynamic Resource Planning}

Current ERP systems management profound impact on the enterprise, which has the following core ideas: (1) ERP system has been widely used in the current enterprise, which integrate information across the enterprise, with powerful functionality; (2) enterprises ERP system will scatter data collection and storage, to further improve data accuracy; (3) companies use ERP system suppliers, raw material acquisition and production sales supply chain for effective management. The core idea of the ERP system has a strong effect, enterprises should make full use of its role, it must be throughout the financial system, and integration of enterprise business processes, combined with the network of financial and ERP systems, to make financial management adapted to the current pace of economic development and the environment. At the same time, ERP systems and financial networks in the late development and integration must be improved. Wherein part of the procurement aspects of the business, through the ERP system only needs to purchase a one-time data input to, and storage and other work areas just need to wait for verification, eliminating the need to re-enter the program. Financial network of suppliers through the Internet information comprehensive understanding, and optionally comparing vendor prices, and credit quality, and the data input ERP system saved; in terms of production processes in the ERP system by the MRP management of the enterprise throughout the production chain, MRP automatically set by the actual situation of production planning; additional terms in the sales cycle, ERP systems control in advance sales, the sales staff through the understanding of market dynamics and inventory information, and to develop strategically Sales Plan.

\section{Conclusion}

In summary, in the environment of the global economy and the rapid development of the Internet, the use of e-commerce era was born, dynamic financial management has far-reaching significance in the enterprise development strategies, in the course of future development, the dynamic financial management model is completely replace the traditional financial management model, enterprises in the competitive environment will be greater development advantages. 


\section{References}

[1] Bian Luocai. Based on working capital management business e-commerce [D]. China Ocean University, 2011.

[2] Li Na. E-commerce Dynamic Financial Management Model [D]. Wuhan University of Technology, 2012.

[3] Yang Daoheng. Age of electronic commerce dynamic financial sector financial Study [J]. management (Academic Edition), 2014,21: 135-163.

[4] Yu Ying, Jiang Qiyue. Our e-commerce business model innovation Financial Management Discussion [J]. Enterprise Review, 2014,24: 63-33.

[5] Shi Guangying. under age of electronic commerce Modes of Dynamic Financial Management [J]. modern business, 2015,06: 229-230. 